\title{
PENGUJIAN ANTI AGING SEDIAAN KRIM CANGKANG BEKICOT (ACHATINA FUNICA) PADA KELINCI (ORYCTOLAGUS CUNICULUS) YANG DIPAPAR SINAR UV
}

\author{
Muhammad Asri, Nielma Auliah \\ Universitas Megarezky \\ Email : muhammadasri324@gmail.com
}

\begin{abstract}
Snail shells is one of the mollusk phyla that contains protein and chitin function as protector from wind. The protector of wind is a process to prevent premature of the skin. This research aimed to find the formulation and efficacy test of snail shel cream (Achatina fulica) on rabbits (Oryctolagus cuniculus) as protector from the wind. The type of this research used experimental method with UV exposure method using Philips light intensity $10 \mathrm{Mw} / \mathrm{cm}^{2}$ where the back skin of animals try to be wrinkled. The samples of snail shells (Achatina fulica) used the powdered shell is then used as the active compound in the cream dosage formulation. Cracked cream shell powder formulas are formulated in four formulas with concentration $0 \%$ (without cracked cream shell powder) $5 \%, 10 \%, 15 \%$, and testing the skin of the rabbit's back (Oryctolagus cuniculus). Treatment is divided into 5 treatments namely treatment 1 as positive control used cream without active compound, treatment 2 concentration cream 5\%, treatment 3 concentration cream 10\%, treatment 4 concentration cream $15 \%$, and treatment 5 as negative control used cream patent as the protector of $x$ wind. The result of this research showed the effectivitas of concentration cream 5\% which had 16,4 $\mathrm{mm}$, and the positive control had $5,7 \mathrm{~mm}$. It can conclude that with concentration $5 \%$ had the most powerful effectiveness than variation in the concentration of other creams
\end{abstract}

Keywords : Snail shells (Achatina fulica), Formulation, The protector of wind

\section{PENDAHULUAN}

Penuaan dini merupakan hal yang ditakuti karena berkaitan erat dengan penampilan. Wajah akan terlihat menua, kulit keriput, kusam, rambut memutih. Diatas usia 40 tahun organ-organ sudah mulai menunjukkan tanda-tanda penuaan. Tetapi penuaan bisa diperlambat dengan hidup sehat (Partic, 2014). Perubahan akibat proses penuaan yang terjadi pada kulit dapat dibagi atas perubahan anatomi, fisiologis, Salah satu perubahan proses penuaan yang dapat dilihat di kulit yaitu munculnya keriput, kulit kering, kusam dan kasar serta timbulnya noda-noda gelap pada kulit yang diakibatkan karena terjadinya penumpukan kerusakan maupun penurunan fungsi biologis dan kemampuan organisme untuk beradaptasi terhadap stress metabolik, hal ini juga disebabkan oleh adanya peningkatan usia, sebagaimana organ yang lain, fungsi kulit pun ikut menurun, karena sel kulit yang mati melekat lebih lama dilapisan terluar kulit akibatnya Produksi kolagen juga mengalami penurunan. Kolagen ini seharusnya menjadi penunjang kulit agar terlihat kencang. Sebagai akibatnya kulit pun akan kehilangan elastisitas. Ditinjau dari kandungan yang terdapat pada cangkang bekicot yaitu mengadung protein $28 \%$, serat kasar $1 \%$, kalsium $25 \%$, dan fosfor $0,14 \%$ (suharto, 1999). Hubungan protein dengan kulit menua yaitu pada produksi kolagen di lapisan epidermis, diketahui bahwa dermis terutama terdiri dari bahan dasar serabut kolagen dan elastin yang berada di dalam substansi dasar yang bersifat koloid dan terbuat dari gelatin mukopolisakarida. Kulit yang kencang dan halus ditentukan dari lapisan dermis. Dalam lapisan epidermis ini yang terdapat kolagen merupakan sekumpulan protein yang kuat dan kencang pada kulit. Kolagen terbentuk dari struktur prokolagen yang diproduksi dan lebih lama dengan bantuan DNA dan aktifitas sel fibroblast. Serta nutrisi yang tepat dapat melambatkan proses pengenduran kulit (Patric, 2014) dan penelitian (Yulianti dkk.2015) terhadap cangkang bekicot juga mengandung senyawa kitin yang berfungsi sebagai senyawa aktif anti aging dalam bentuk murni kitosan yang terdapat pada cangkang bekicot yang memiliki struktur molekular yang menyerupai asam Hialuronat sehingga menjadikan kitin sebagai senyawa yang dapat memperbaiki sawar kulit, meningkatkan kelembapan, dan senyawa antiaging yang efektif (Yulianti, 2015). Kitin ataupun Kitosan merupakan polisakarida alami yang menyusun jaringan ikat. Fungsi utama molekul ini adalah untuk menstabilkan struktur interseluler (bagian dalam sel) dan membentuk matriksfluida untuk tempat pengikatan kolagen dan serat elastik. Didalam tubuh, terdapat dalam wujud gel pada kulit. seiring dengan bertambahnya usia, jumlah asam hialuronat 
dikulit akan menurun sehingga menyebabkan peningkatan kerutan. Kitin yang memiliki struktur yang menyerupai asam hialuronat memiliki kapasitas yang lebih besar untuk mempertahankan kelembapan. Hal inilah Kitin dianggap sebagai bahan penting untuk anti aging, karena keremajaan kulit sangat berkaitan kadar kelembapan kulit, dengan adanya asam hialuronat yang dapat meningkatkan kadar kelembaban kulit sekaligus memperkuat mempertahankan lapisan terluar kulit (epidermis) akan membuat kulit lembut,halus,dan juga kencang. Kitin bekerja dengan mengikat air sebagai pelumas air dalam kulit yang terdapat pada epidermis dengan mengisi antara kolagen dan elastin. (Murlistyarini, 2015). Tujuan untuk membuat formulasi krim cangkang bekicot yang berkhasiat sebagai anti aging (anti penuaan) terhadap kelinci dengan metode paparan sinar UV (ultraviolet) dengan mengukur kerutan yang terlihat apakah ada perbedaan yang signifikan setiap perlakuan.

\section{BAHAN}

Bahan yang digunakan tween 80 , span 80, asam stearat, parafin, Cetyl alcohol, gliserin, oleum citrii, propylen glikol, asam sitrat, natrium hidroksida, aqua destilata, dan serbuk cangkang bekicot, krim paten anti aging $x$ kertas $\mathrm{pH}$ universal.

\section{METODE}

Penelitian ini dilakukan secara eksperimental laboratorium. Eksperimental merupakan penelitian yang memanipulasi atau mengontrol situasi alamiah dengan cara membuat kondisi buatan (artificial condition) dan membuat formula sediaan krim cangkang bekicot.

\section{Prosedur Kerja :}

Alat dan bahan yang digunakan disiapkan masing-masing bahan ditimbang sesuai dengan perhitungan. Fase minyak dibuat dengan melebur asam stearat, cetyl alcohol, paraffin, dan span 80 sesuai masing-masing formula pada suhu $70^{\circ} \mathrm{C}$ menggunakan penangas air sampai homogen. Sedangkan fase air dibuat dengan melebur gliserin, propilen glikol, dan tween 80 pada suhu $70^{\circ} \mathrm{C}$ sampai homogen. Kemudian fase minyak ditambahkan kedalam fase air dan diaduk sampai homogen pada suhu $70^{\circ} \mathrm{C}$. saat krim mulai dingin (sekitar suhu $40^{\circ} \mathrm{C}$ ), ditambahkan oleum citrii dan serbuk cangkang bekicot kedalam sediaan sambil tetap di aduk sampai menjadi dingin. Jika terlalu asam maka dilakukan penambahan larutan $\mathrm{pH}$ adjuster yaitu asam sitrat, jika terlalu basa yaitu natrium hisroksida.

\section{Evalusi Sediaan :}

1. Uji organoleptis

Pemeriksaan organoleptis meliputi bentuk, warna, dan bau yang diamati secara visual. Spesifikasi krim yang harus dipenuhi adalah memiliki konsistensi lembut, warna sediaan homogen, dan baunya harum (Safitri dkk, 2014)

2. Uji homogenitas fisik

Sejumlah krim yang akan diamati dioleskan pada kaca objek yang bersih dan kering sehingga membentuk suatu lapisan yang tipis, kemudian ditutup dengan kaca preparat (cover glass). Krim dinyatakan homogen apabila pada pengamatan menggunakan mikroskop, krim mempunyai tekstur yang tampak rata dan tidak menggumpal (Safitri dkk, 2014)

3. $\mathrm{Uji} \mathrm{pH}$

Pemeriksaan $\mathrm{pH}$ dilakukan dengan menggunakan alat $\mathrm{pH}$ meter yaitu $\mathrm{pH}$ indikator universal. Kertas universal dicelupkan kedalam krim kemudian diamati perubahan warna yang terjadi dan bandingkan perubahan warna dengan warna standar. Krim sebaiknya memiliki $\mathrm{pH}$ yang sesuai dengan $\mathrm{pH}$ kulit yaitu 4,5-6,5 ( Safitri dkk, 2014)

4. Uji daya lekat

Pengujian daya lekat sediaan dilakukan dengan cara krim diletakkan pada satu sisi kaca objek dengan sisi bawahnya telah dipasangkan tali untuk mengikat beban. Kemudian ditempelkan pada kaca objek yang lain. Beban yang digunakan adalah $50 \mathrm{~g}$. kemudian diamati waktu yang dibutuhkan beban tersebut untuk memisahkan kedua kaca tersebut (Safitri dkk, 2014). 


\section{Evaluasi Daya Anti Aging Krim Serbuk Cangkang Bekicot}

Penelitian dilakukan selama 14 hari menggunakan 2 ekor kelinci, di bagi atas 5 perlakuan :

P1 : paparan UV, pemberian krim tanpa serbuk cangkang bekicot

P2 : paparan sinar UV, pemberian krim cangkang bekicot dengan konsentrasi $5 \%$
P3 : paparan sinar UV, pemberian krim cangkang bekicot dengan konsentrasi $10 \%$

P4 : paparan sinar UV, pemberian krim cangkang bekicot dengan konsentrasi $15 \%$

P5 : paparan UV, pemberian krim anti aging

Pengujian krim anti aging dilakukan dengan mengamati efek berkurang dan hilangnya pengkerutan pada kulit hewan uji yang papar dengan sinar UV.

\section{HASIL PENELITIAN}

\section{A. Uji evaluasi sediaan Kri}

Tabel 1.

Data Hasil uji organoleptis sediaan krim

\begin{tabular}{lllll}
\hline \multirow{2}{*}{ Uji } & \multicolumn{4}{c}{ Hasil pengamatan } \\
\cline { 2 - 5 } & \multicolumn{1}{c}{ F1 } & F2 & \multicolumn{1}{c}{ F3 } & \multicolumn{1}{c}{ F4 } \\
\hline Warna & putih & Abu muda & Abu-abu & Abu tua \\
Bau & Harum & Harum & Harum & Harum \\
bentuk & Krim & Krim & Krim & Krim \\
konsistensi & Lembut & Lembut & Lembut & Sedikit kasar \\
\hline
\end{tabular}

Tabel 2.

Data Hasil uji homogenitas fisik

\begin{tabular}{ccccc}
\hline \multirow{2}{*}{ Uji } & \multicolumn{4}{c}{ Hasil pengamatan } \\
\cline { 2 - 5 } & F1 & F2 & F3 & F4 \\
\hline Homogenitas & Homogen & Homogen & Homogen & Homogen \\
\hline
\end{tabular}

Tabel 3.

Data Hasil uji pH

\begin{tabular}{ccccc}
\hline \multirow{2}{*}{ Uji } & \multicolumn{4}{c}{ Hasil pengamatan } \\
\cline { 2 - 5 } & $\mathrm{F} 1$ & $\mathrm{~F} 2$ & $\mathrm{~F} 3$ & $\mathrm{~F} 4$ \\
\hline $\mathrm{pH}$ & 5 & 6 & 6 & 6 \\
\hline
\end{tabular}

Tabel 4.

Data Hasil uji daya lekat

\begin{tabular}{rcccc}
\hline \multirow{2}{*}{ Berat beban } & \multicolumn{4}{c}{ Waktu pemisahan krim } \\
\cline { 2 - 5 } & $\mathrm{F} 1$ & $\mathrm{~F} 2$ & $\mathrm{~F} 3$ & $\mathrm{~F} 4$ \\
\hline Uji Daya & 2,02 & 1,52 & 1,22 & 48,54 \\
lekat & menit & menit & menit & detik \\
\hline \multicolumn{4}{c}{ Keterangan : } \\
F1 & $=$ Krim tanpa serbuk cangkang bekicot \\
F2 & $=$ Krim cangkang bekicot (5\%) \\
F3 & $=$ Krim cangkang bekicot $(10 \%)$ \\
F4 & $=$ Krim cangkang bekicot $(15 \%)$
\end{tabular}


Tabel 5.

Data Hasil uji efektivitas sediaan krim

\begin{tabular}{ccc}
\hline \multirow{2}{*}{ Perlakuan } & \multicolumn{2}{c}{ Diameter Keriput (mm) } \\
\cline { 2 - 3 } & Minggu 1 & Minggu 2 \\
\hline P1 & 26,5 & 27,1 \\
P2 & 14,9 & 9,6 \\
P3 & 17,3 & 12,8 \\
P4 & 18,4 & 16,4 \\
P5 & 6,1 & 5,7 \\
\hline
\end{tabular}

\footnotetext{
Keterangan :

$\mathrm{P} 1=$ perlakuan dengan krim tanpa zat aktif sebagai kontrol negatif

$\mathrm{P} 2$ = Perlakuan dengan krim konsentrasi 5\%

P3 = Perlakuan dengan krim konsentrasi 10\%

P4 = Perlakuan dengan krim konsentrasi 15\%

P5 = Perlakuan dengan krim paten sebagai kontrol positif
}

Gambar 1.

Grafik uji efektivitas sediaan krim cangkang bekicot (Achatina fulica)

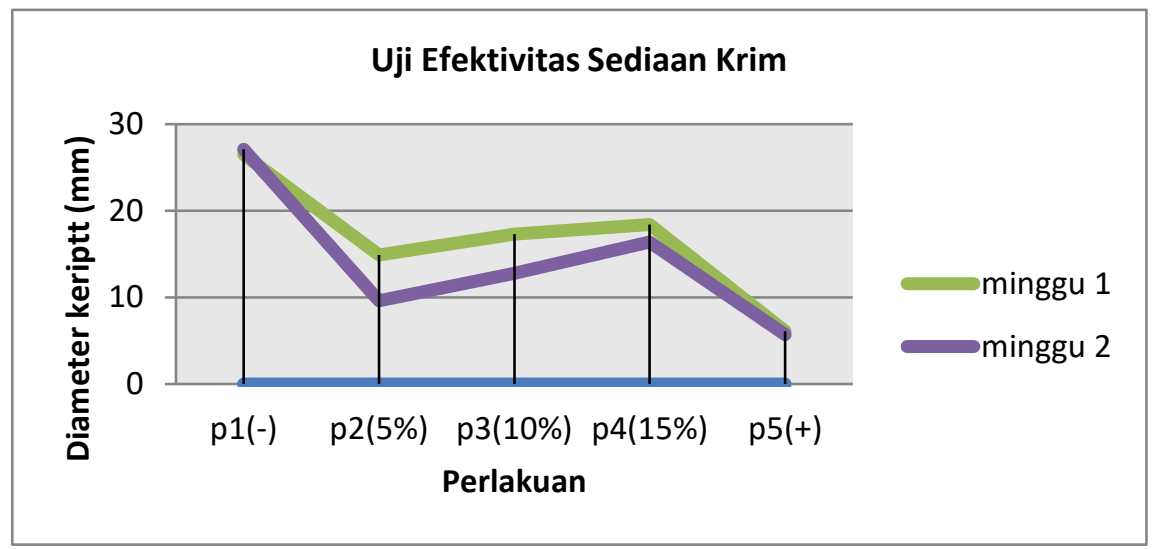

\section{PEMBAHASAN}

Bekicot (Achatina fulica) yang digunakan didalam penelitian ini merupakan zat aktif uatama yang memiliki efektivitas untuk menghambat adanya penuaan dini karena senyawa kitin dan protein yang dikandungnya. Bagian bekicot yang digunakan adalah cangkangnya yang diserbukkan dan kemudian dibuat dalam bentuk sediaan krim dengan konsentrasi $5 \%, 10 \%$, dan $15 \%$.

Evaluasi akhir untuk mengetahui kelayakan penggunaan sediaan krim dilakukan setelah pembuatan sediaan krim selesai. Kriteria yang dapat diamati adalah uji organoleptis, uji homogenitas, uji $\mathrm{pH}$, dan uji daya lekat. Pada uji organoleptis didapat hasil bahwa warna krim pada formula 1 yaitu berwarna putih, formula 2 yaitu berwarna abu muda, formula 3 yaitu berwarna abu tua (Tabel 1). Sediaan krim berbau harum dan memiliki konsistensi krim yang baik. Secara fisik, sediaan krim juga diuji menggunakan uji homogenitas fisik dimana sediaan krim tidak boleh terdapat gumpalan - gumpalan partikel didalamnya (Safitri dkk, 2014). Hasil yang didapatkan pada pengujian ini adalah krim bersifat homogen karena semua partikel yang ada didalam krim tersebar merata, uji homogenitas juga dilakukan dengan menggunakan mikroskop untuk mengamati ada tidaknya gumpalan didalam krim, dari hasil pengamatan menggunakan mikroskop diketahui bahwa pada keempat formula sediaan krim tidak mengalami penggumpalan. Tetapi formula 1,2 dan 3 menunjukkan hasil yang lebih baik dibandingkan dengan formula 4 (Tabel 2). Hasil pengujian $\mathrm{pH}$ dengan menggunakan kertas $\mathrm{pH}$ universal, formula 1 berada $\mathrm{pH} 5$ 
dan formula 2,3,4 berada pada $\mathrm{pH} 6$ (Tabel 3). Dengan nilai $\mathrm{pH}$ keempat formula sesuai dengan $\mathrm{pH}$ kulit yaitu 4,5 - 6,5. Sehingga aman untuk diaplikasikan kekulit, $\mathrm{pH}$ sediaan harus berada dalam rentang $\mathrm{pH}$ kulit. Untuk mencegah terjadinya iritasi pada kulit (Tranggono \& fatma, 2007). Pengujian sediaan dilanjutkan dengan uji daya lekat, hasil daya lekat menunjukkan bahwa daya lekat formula 1 dan 2 lebih besar dibandingkan formula 3 dan 4 dengan waktu pelepasan formula 1 yaitu 2,02 menit, formula 2 yaitu 1,52 menit, sedangkan formula yaitu 1,22 menit dan formula 4 yaitu 48,54 detik (Tabel 4). Semakin lama waktu yang diperlukan hingga kedua objek glass terlepas. Maka makin baik daya melekat sediaan krim tersebut, semakin lama krim melekat pada kulit maka efek yang ditimbulkan juga semakin besar,dengan daya lekat yang besar memilki keuntungan untuk berpenetrasi kekulit dengan baik karena emulgator dapat berinteraksi dengan baik terhadap lemak dan protein kulit (Safitri dkk, 2014).

Anti aging yang diformulasi dalam bentuk sediaan topikal diharapkan mampu melindungi kulit dari efek sinar matahari yang merugikan dalam bentuk sediaan krim. Krim adalah sediaan setengah padat, berupa emulsi yang mengandung air tidak kurang dari $60 \%$ dan dimaksudkan untuk pemakaian luar, sediaan krim digunakan karena sediaan ini merupakan sediaan yang menyenangkan, mudah menyebar merata, dan praktis digunakan (Ansel, 2008). Adapun untuk mengetahui efektivitas sediaan krim serbuk cangkang bekicot (Achatina fulica) sebagai anti aging yaitu dengan dihitung dari banyaknya kerutan yang diakibatkan oleh paparan sinar UV pada kulit. Semakin banyak kerutan yang ditimbulkan menunjukkan krim tidak berfungsi dengan baik pada kulit, pengujian ini dilakukan dengan mengukur diameter keriput menggunakan jangka sorong digital. Pengujian efektivitas antiaging dimulai dengan membandingkan kondisi awal kulit punggung kelinci sebelum perlakuan kemudian dilanjutkan dengan mengukur diameter keriput pada perlakuan minggu ke 1 dan minggu ke 2. Hal tersebut bertujuan untuk melihat perubahan signifikan dari keriput yang ditimbulkan oleh pemaparan dan setelah pengolesan masing - masing sediaan krim uji. Pengujian efektivitas anti aging dibagi atas
5 perlakuan krim tanpa senyawa aktif $(0 \%)$ sebagai kontrol negatif, krim dengan konsentrasi $5 \%$, krim dengan konsentrasi $10 \%$, krim dengan konsentrasi $15 \%$, dan krim paten anti aging wardah sebagai kontrol positif. Krim yang digunakan sebagai kontrol positif memiliki 5 kandungan aktif yaitu ekstrak gula mapel (Acer saccharum) yang bekerja sebagai alfa hidroksi alami yang sering digunakan dalam produk perawatan kulit untuk meminimalkan dan memperbaiki kerusakan sel yang disebabkan oleh radikal bebas (Joseph dkk, 2008) ; ekstrak buah lemon (Citrus medica limonom) dan ekstrak buah jeruk (Citrus aurantum dulcis) yang kaya akan kandungan vitamin $\mathrm{C}$, ketika digunakan dalam perawatan kulit anti aging dapat meransang produksi kolagen (Juanda dkk, 2013) ; ekstrak buah tebu (Saccharum officinarum) yang mengandung asam glikolat (Abadi \& Joshita, 2013) ; ekstrak buah blueberry yang memiliki khasiat antioksidan luar biasa (Joseph dkk, 2008). Berdasarkan data pengamatan (Tabel. 5), dapat dilihat secara jelas terdapat perbedaan pengukuran diameter pada minggu ke 1 dan minggu ke 2 . Selain dilihat dari segi pengukuran tampak jelas bahwa krim cangkang bekicot dengan konsentrasi $5 \%$ dan $10 \%$ lebih efektif menurunkan jumlah keriput dibandingkan dengan konsentrasi $15 \%$ sedangkan pada kontrol negativ menunjukkan adanya peningkatan pengkeriputan. Hal ini tidak menunjukkan bahwa semakin tinggi konsentrasi zat aktif dalam suatu sediaan maka, semakin tinggi tingkat efektivitas yang dimiliki suatu sediaan, yang terjadi adalah malah sebaliknya. Demikian disebabkan karena adanya konsentrasi zat aktif yang tidak sebanding dengan bahan dasar pembuatan sediaan krim yaitu dengan serbuk cangkang bekicot dengan konsentrasi $15 \%$ berdasarkan uji evaluasi sediaan menunjukkan daya lekat yang kurang baik sehingga menyebabkan senyawa aktif kurang baik berpenetrasi dikulit dan mengurangi daya absorbsi obat topikal kekulit.

\section{KESIMPULAN}

Berdasarkan hasil penelitian yang telah dilakukan dapat disimpulkan bahwa sediaan krim cangkang bekicot (Achatina fulica) memiliki efektivitas sebagai anti 
aging dan krim dengan konsentrasi 5\% memiliki efektivitas lebih kuat.

\section{DAFTAR PUSTAKA}

Abadi DN., and Joshita djajadisastra., 2013. Uji Manfaat Krim ekstrak limbah batang tebu (Saccharum officinarum) yang berguna sebsgai pencerah kulit. [Tesis]. Universitas Indonesia. diakses 5 juni 2018.

Joseph James A., Daniel A. Nadeau., and Anne Underwood., 2008. Diet sehat dengan kode warna makanan. Hikmah PT Mizan Publika. Jakarta selatan. diakses 5 juni 2018.

Juanda D., Wempi B., Ridwan IM., 2013. Penetapan Kadar Total Fenol dan Aktivitas Antioksidan dari Jus Buah Lima Spesies Jeruk (Cirus sp.). Jurnal farmasi galenika. 2 : $36-42$. diakses 5 juni 2018.

Murlistyarini, S, 2014. Pengelupasan Kulit Secara Kimiawi. Penerbit UB Press. Malang.
Safitri, A.N., Oktavia E.P., dan Valentina Y., 2014. Optimasi Formula Sediaan Krim Ekstrak Stroberi (Fragaria $x$ ananassa) sebagai Krim Anti Penuaan. Jurnal kesehatan FKUB.1 : 235 - 246. diakses 16 Agustus 2018.

Tranggono R.S, dan Fatma L., 2007. Buku Pegangan IImu Pengetahuan Kosmetik. Gramedia pustaka utama. Jakarta.

Partic, L., 2014.Perisai Segala Penyakit. PT Elex Media Komputindo Kelompok Gramedia. Jakarta.

Yulianti, L., Bramono, K., Mardliyati, E., dan Freisleben, H.J., 2015,. Jurnal Penelitian. Ekspresi Protein Aquaporin3 Pada Fibroblas dan Keratinosit Kulit manusia yang Diinduksi oleh Ekstrak Etanol Centella Asiatica Dalam Nanopartikel Kitosan. Vol. 42 : $7 \mathrm{~s}-17 \mathrm{~s}$. diakses 09 Agustus 2018. 